Prepared for the U.S. Department of Energy under Contract DE-AC05-76RL01830

\title{
Whole Algae Hydrothermal Liquefaction: 2014 State of Technology
}

SB Jones

Y Zhu

LJ Snowden-Swan

DB Anderson

RT Hallen

AJ Schmidt

KA Albrecht

DC Elliott

June 2014 


\title{
DISCLAIMER
}

This report was prepared as an account of work sponsored by an agency of the United States Government. Neither the United States Government nor any agency thereof, nor Battelle Memorial Institute, nor any of their employees, makes any warranty, express or implied, or assumes any legal liability or responsibility for the accuracy, completeness, or usefulness of any information, apparatus, product, or process disclosed, or represents that its use would not infringe privately owned rights. Reference herein to any specific commercial product, process, or service by trade name, trademark, manufacturer, or otherwise does not necessarily constitute or imply its endorsement, recommendation, or favoring by the United States Government or any agency thereof, or Battelle Memorial Institute. The views and opinions of authors expressed herein do not necessarily state or reflect those of the United States Government or any agency thereof.

\author{
PACIFIC NORTHWEST NATIONAL LABORATORY \\ operated by \\ BATTELLE \\ for the \\ UNITED STATES DEPARTMENT OF ENERGY \\ under Contract DE-AC05-76RL01830 \\ Printed in the United States of America \\ Available to DOE and DOE contractors from the \\ Office of Scientific and Technical Information, \\ P.O. Box 62, Oak Ridge, TN 37831-0062; \\ ph: (865) 576-8401 \\ fax: $(865) 576-5728$ \\ email: reports@adonis.osti.gov

\footnotetext{
Available to the public from the National Technical Information Service,

U.S. Department of Commerce, 5285 Port Royal Rd., Springfield, VA 22161

ph: (800) 553-6847

fax: (703) 605-6900

email: orders@ntis.fedworld.gov

online ordering: http://www.ntis.gov/ordering.htm
}

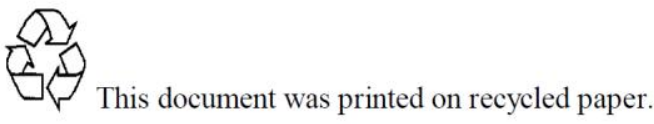




\title{
Whole Algae Hydrothermal Liquefaction: 2014 State of Technology
}

\author{
SB Jones \\ Y Zhu \\ LJ Snowden-Swan \\ DB Anderson \\ RT Hallen \\ AJ Schmidt \\ KA Albrecht \\ DC Elliott
}

June 2014

Prepared for

the U.S. Department of Energy

under Contract DE-AC05-76RL01830

Pacific Northwest National Laboratory

Richland, Washington 99352 



\section{Contents}



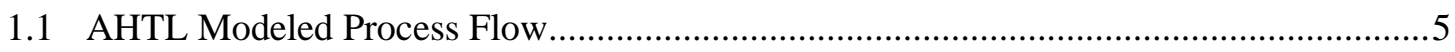

1.2 Feedstock and Feedstock Preparation Model Description and Input Data.........................5

1.3 Hydrothermal Liquefaction Model Description and Input Data .....................................6

1.4 AHTL Oil Catalytic Upgrading Model Description and Input Data .................................9

1.5 Aqueous Phase Catalytic Hydrothermal Gasification (CHG) Model Description and

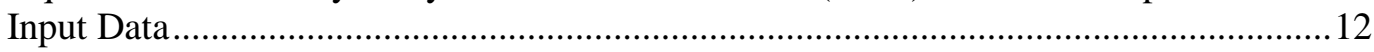

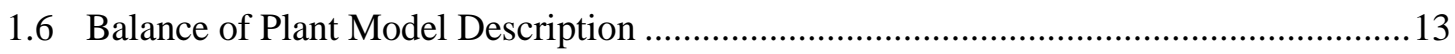

2.0 Environmental Sustainability Metrics .............................................................................. 14

3.0 Conversion Progression to 2022 Design Case .................................................................. 16

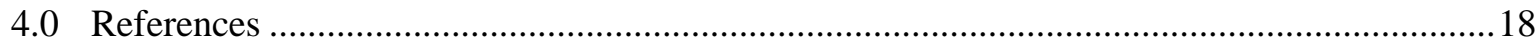

\section{Figures}

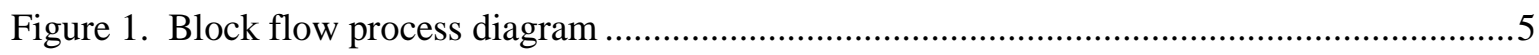

Figure 2. Continuous flow experimental reactor configuration used to generate data for the SOT

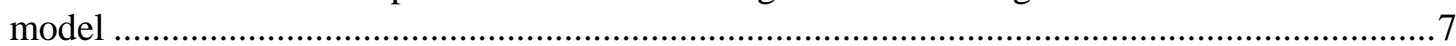

Figure 3. Experimentally derived hydrotreated AHTL oil distillation curves .............................. 10

Figure 4. Estimated hydrotreated product distribution ............................................................ 10

Figure 5. Modeled final product distribution ........................................................................ 11

Figure 6. Modeled conversion cost progression ......................................................................... 16

\section{Tables}

Table 1. Algal biomass elemental composition (dry basis)

Table 2. AHTL continuous flow experimental results used in the SOT model and the 2022 projected modeled assumptions ..... .7

Table 3. Hydrotreating continuous flow experimental results used in the SOT model and

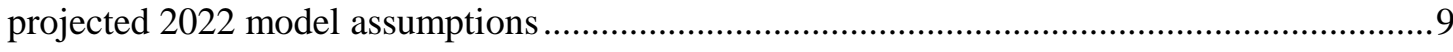

Table 4. CHG continuous flow experimental results and projected model assumptions .................12

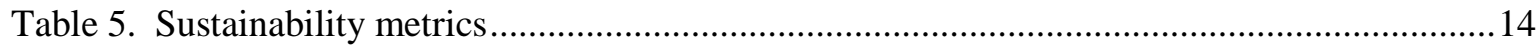

Table 6. Modeled costs for the 2014 SOT and the 2022 projection............................................ 17 


\subsection{State of Technology R\&D for 2014}

The Bioenergy Technologies Office's (BETO) overarching strategic goal is "to develop commercially viable biomass utilization technologies to enable the sustainable, nationwide production of advanced biofuels that are compatible with today's transportation infrastructure and can displace a share of petroleum-derived fuels to reduce U.S. dependence on oil and encourage the creation of a new domestic bioenergy industry supporting the EISA goal of 36 bgy of renewable transportation fuels by 2022" (US DOE, 2014). As such, BETO supports research and development (R\&D) activities related to conversion of terrestrial feedstocks (e.g. wood, agricultural residues, energy crops) and algal feedstocks to liquid transportation fuels.

The Conversion R\&D technical element of the Office measures R\&D progress by setting performance goals towards a future target. Modeled scenarios, in close collaboration with researchers, are used to perform conceptual evaluations termed "design cases". These provide a detailed basis for understanding the potential of conversion technologies and help identify technical barriers where research and development could lead to significant cost improvements. The whole algae hydrothermal liquefaction (AHTL) and upgrading to fuels design case (Jones 2014) details the technical and economic targets expected to be achievable by 2022 .

Each year, BETO assesses their research progress in two ways: via technical targets achieved experimentally and through modeled production cost targets. Experimental data from their R\&D portfolio is incorporated into commercial-scale techno-economic models, from which production costs are estimated. Published data are also used, when available, to capture the current state of the art for a given technology. The state of technology (SOT) R\&D model and accompanying report reflect the minimum fuel selling price (MFSP) for the technology, modeled as an $\mathrm{n}^{\text {th }}$ plant ${ }^{1}$ obtaining a $10 \%$ internal rate of return at a net present value of zero. Economic assumptions are consistent across BETO design cases and SOTs, to allow standardization of an economic basis for technology comparisons ${ }^{2}$. This standardization does not account for differing levels of maturity amongst technologies under investigation, thus SOTs play an important role in documenting current thinking about data gaps and research needs. New projections for annual cost targets are then developed and documented as a reference for BETO's Multi-Year Program Plan ${ }^{2}$. Finally, the SOT captures the current state of sustainability indicators, based on modeled inputs and outputs for the technology in the context of an $n^{\text {th }}$ plant design, including greenhouse gas (GHG) emissions, fossil energy consumption, total fuel yield per ton of biomass, carbon-to-fuel efficiency, water consumption, and wastewater generation.

This State of Technology report documents the experimental data used to estimate the modeled costs for AHTL research as is stands today and as compared to the assumptions used in the design case. This establishes the base case conditions against which future technical and economic improvements will be measured. The process models used for this SOT report are based on experimental data from the Pacific Northwest National Laboratory (PNNL). Technical and economic targets for the interim years between now and 2022 are being developed and will be published in a separate report in FY15.

\footnotetext{
1 “ $\mathrm{n}$ th" plant design assumptions do not account for additional first of a kind plant costs, including special financing, equipment redundancies, large contingencies and longer startup times necessary for the first few plants. For $\mathrm{n}^{\text {th }}$ plant designs, it is assumed that the costs reflect a future time when the technology is mature and several plants have already been built and are operating.

${ }^{2}$ Current and historical economic assumptions may be found in Appendix C of BETO's Multi-Year Program Plan (US DOE 2014).
} 


\subsection{AHTL Modeled Process Flow}

Figure 1 shows the block flow diagram for algae conversion via hydrothermal liquefaction and upgrading as modeled in AspenPlus. Conversion refers to the processes inside of the dashed lines. Dewatered algae (20 wt $\%$ on an ash free basis) are pumped to the HTL reactor. Condensed phase liquefaction then takes place through the effects of time, heat and pressure. The resulting AHTL products (oil, solid, aqueous, gas) are separated and the AHTL oil is hydrotreated to form diesel and some naphtha range fuels. The AHTL aqueous phase is catalytically treated to recover the carbon content and allow water recycle back to the ponds. Process off gas may be used to generate hydrogen, heat and/or power. A hydrogen source is included as hydrotreating is assumed to be co-located with the algae ponds and AHTL conversion. Nutrient recovery is assumed to be accomplished by recycling treated water, carbon dioxide containing flue gas, and treated solids back to the algae ponds.

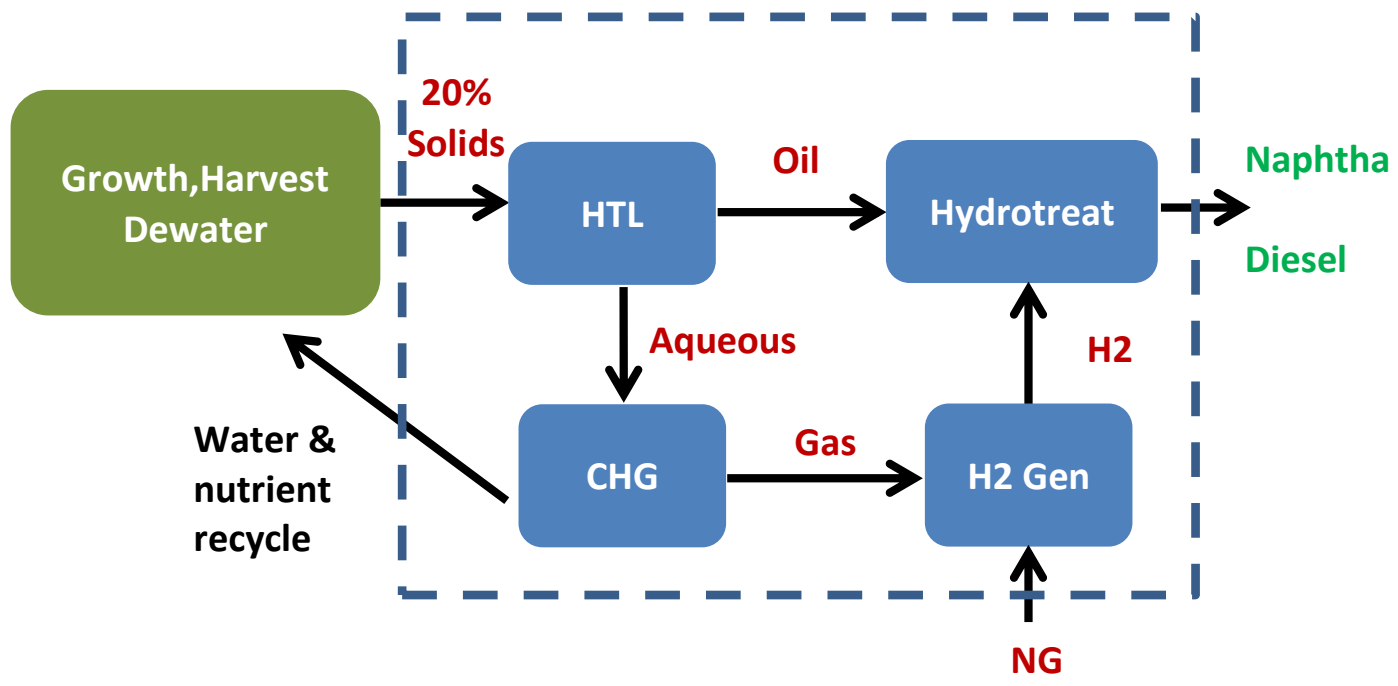

Figure 1. Block flow process diagram

Offsite AHTL oil upgrading, by transporting the AHTL oil to a centralized upgrader, will be considered in the future, when use of existing infrastructure becomes better understood.

\subsection{Feedstock and Feedstock Preparation Model Description and Input Data}

Algal processing differs from lignocellulosic-based biomass refineries in that feedstock production and conversion to fuels or fuel intermediates will be co-located and interdependent. However, consistent with AHTL design case, the operations associated with cultivation, harvest and dewatering the algae prior to AHTL conversion are outside of the scope of the experimental work supporting algae conversion and are not included in this analysis.

A joint project between Argonne National Laboratory (ANL), the National Renewable Energy Laboratory (NREL) and PNNL (known as the "AHTL harmonization project') integrated resource assessment, algal fuel production and sustainability (Davis 2014). As discussed in the design case and the AHTL harmonization work, the results suggest that on a national scale, there can be a significant difference in production rates between summer and winter depending upon the location. The SOT work assumes a 5-to-1 fluctuation between summer and winter production and resulting feed rate to the AHTL conversion plant, 
consistent with the design case (Jones 2014) and the harmonization work (Davis 2014). To mitigate this effect, a portion of the algae is dried during the high season for later use. Approximately $30 \mathrm{wt} \%$ (AFDW) of the wet algae produced during the summer months is dried from $80 \mathrm{wt} \%$ moisture to $10 \mathrm{wt} \%$ moisture. The natural gas usage needed for drying has a significant sustainability impact and alternate means of addressing seasonal variability needs investigation.

Table 1 lists the algal characteristics used in the AspenPlus models. The 2014 SOT data are measured results from the feedstock used in the experiments. The 2022 design case characteristics are assumptions based on experimental data.

Table 1. Algal biomass elemental composition (dry basis)

\begin{tabular}{|c|c|c|c|c|}
\hline \multirow{2}{*}{$\begin{array}{c}\text { Algal } \\
\text { Characteristics } \\
\text { Component } \\
\end{array}$} & \multicolumn{2}{|c|}{$\begin{array}{c}\text { Experimental data used in the } 2014 \\
\text { SOT model }\end{array}$} & \multicolumn{2}{|c|}{$\begin{array}{l}\text { Projected data (based on } \\
\text { experimental results) used in the } \\
2022 \text { Design Case model }\end{array}$} \\
\hline & Wt\% & Wt\% ash free & Wt\% & Wt\% ash free \\
\hline $\mathrm{C}$ & 38.6 & 49.4 & 52 & 60 \\
\hline $\mathrm{H}$ & 5.3 & 6.9 & 7.5 & 8.6 \\
\hline $\mathrm{O}$ & 27.5 & 35.3 & 22 & 25 \\
\hline $\mathrm{N}$ & 5.0 & 6.4 & 4.8 & 5.5 \\
\hline $\mathrm{S}$ & 1.6 & 2.0 & 0.61 & 0.7 \\
\hline ash & 22 & & 13 & \\
\hline $\mathrm{P}$ & 0.4 & & 0.6 & \\
\hline 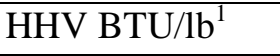 & & 9,290 & & 12,140 \\
\hline
\end{tabular}

\section{Feedstock quality and availability: Current versus Projected}

- There are known compositional differences between strains of algae, and typically seasonal variations as well. Strains need to be better understood in terms of AHTL processing, particularly for species screened and/or developed for high growth as opposed to lipid production. The strains used for this SOT case may not be the optimal choice for the future.

- Detailed algal feed characterization is needed to assist in determination of the tradeoffs (if any) between species, lipid content, ash characteristics and final product yield and quality, and the availability of recoverable nutrients.

\subsection{Hydrothermal Liquefaction Model Description and Input Data}

Figure 2 shows a schematic of the experimental HTL test set up from which data were obtained for use in the AspenPlus models. The experimental results used in the SOT models and the projected modeled inputs for the 2022 design case are shown in Table 2. The SOT modeled inputs were taken from experiments conducted in a continuous stirred tank (CSTR) - plug flow reactor (PFR) configuration. While this hybrid scheme was used in the experimental work, stirred tank reactors are deemed impractical at the commercial scale assumed for the models because of size and cost. Thus, plug flow reactor systems are assumed in the cost analysis. Future experimental work will focus on the use of PFRs only. 


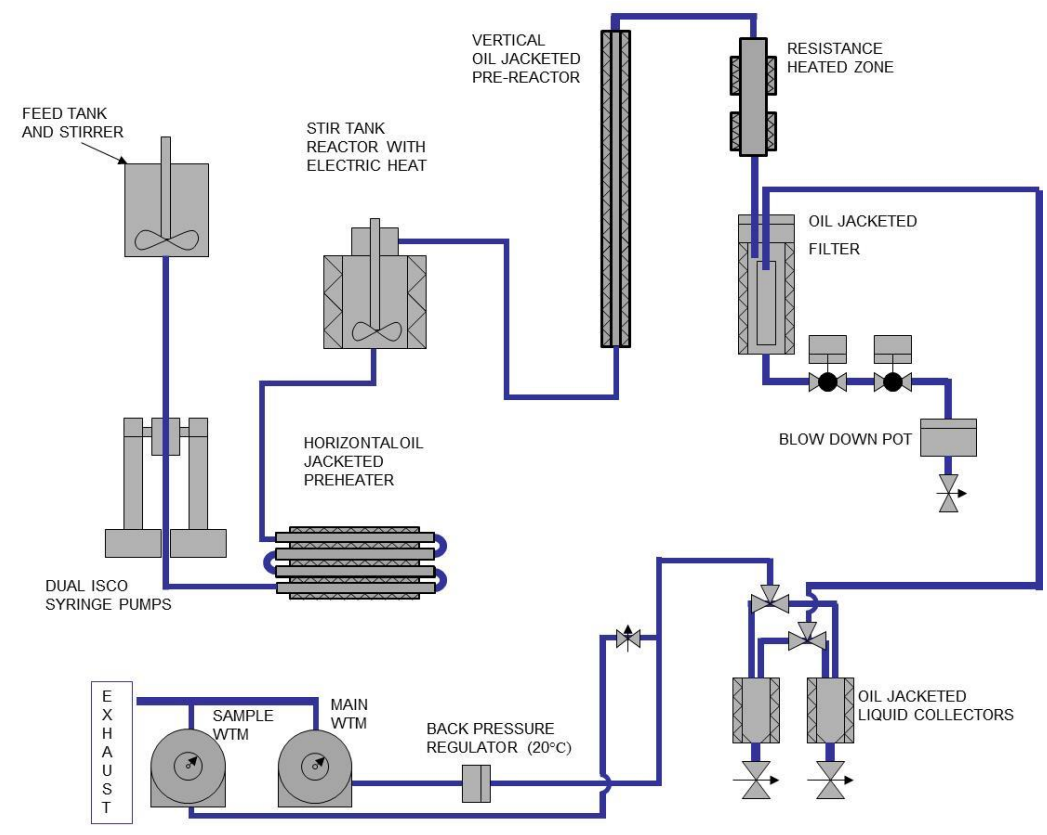

Figure 2. Continuous flow experimental reactor configuration used to generate data for the SOT model

Table 2. AHTL continuous flow experimental results used in the SOT model and the 2022 projected modeled assumptions

\begin{tabular}{|c|c|c|}
\hline $\begin{array}{l}\text { Operating Conditions, Product Yields and } \\
\text { HTL Oil Characteristics }\end{array}$ & $\begin{array}{c}\text { SOT } \\
\text { Experimentally } \\
\text { Derived Model Inputs } \\
\text { (avg. of three) }\end{array}$ & $\begin{array}{l}2022 \text { Input to } \\
\text { Modeled } \\
\text { Projection }\end{array}$ \\
\hline Temperature, ${ }^{\circ} \mathrm{F}\left({ }^{\circ} \mathrm{C}\right)$ & $667(350)$ & $660(349)$ \\
\hline Pressure, psia & 3000 & 3000 \\
\hline $\begin{array}{ll}\text { Feed solids, wt } \% & \begin{array}{l}\text { Ash included } \\
\text { Ash free basis }\end{array}\end{array}$ & $\begin{array}{l}22.0 \\
20.0\end{array}$ & $\begin{array}{l}22.3 \\
20.0\end{array}$ \\
\hline $\begin{array}{l}\text { LHSV, vol./h per vol. reactor } \\
\text { Equivalent residence time, minutes }\end{array}$ & $\begin{array}{l}2.2 \\
27\end{array}$ & $\begin{array}{c}4 \\
15\end{array}$ \\
\hline Experimental run length, hours & 8 & Not applicable \\
\hline HTL dry oil yield (dry, ash free algae), wt $\%$ & 40 & 59 \\
\hline $\begin{array}{l}\text { Product yields, lb/100 lb dry algae+ash } \\
\text { HTL Oil (dry) } \\
\text { Aqueous organic }+ \text { ash } \\
\text { Gas } \\
\text { Filter solids }\end{array}$ & $\begin{array}{l}31 \\
47 \\
12 \\
10\end{array}$ & $\begin{array}{c}51 \\
43 \\
4 \\
2\end{array}$ \\
\hline $\begin{array}{l}\text { HTL dry oil analysis, wt\% } \\
\text { C } \\
\text { H } \\
\text { O } \\
\text { N } \\
\text { S } \\
\text { Ash }\end{array}$ & $\begin{array}{c}80.4 \\
9.9 \\
3.5 \\
5.4 \\
0.74 \\
0.6\end{array}$ & $\begin{array}{c}77.0 \\
10.4 \\
8.0 \\
4.2 \\
0.3 \\
0.14\end{array}$ \\
\hline HTL oil density & 0.98 & 0.94 Aspen est. \\
\hline Aqueous phase COD & 73,000 & 63,600 Aspen \\
\hline
\end{tabular}




\section{Observations and Comments after Modeling the AHTL SOT Case}

- The operating conditions used in the experiments that generated the data for the SOT models closely match those projected for 2022, with the exception of space velocity and product yield. For the SOT cases, with lower space velocity, four hydrothermal liquefaction reactors and associated heat exchangers are operating in parallel versus two for the 2022 goal case. AHTL is a high pressure operation and the capital costs are significant. Future work is planned to study the effects of higher space velocity. Also, understanding reaction rates and products from algal components such as, lipids, carbohydrates and, proteins, will help optimize reactor design and improve cost estimates.

- The yield of oil is $40 \mathrm{wt} \%$ on a dry basis, in contrast to the 2022 goal of $59 \mathrm{wt} \%$. HTL oil yield is a function of residence time, temperature, feed solids concentration and algae characteristics. Preliminary data from PNNL for both Nannochloropsis and Tetraselmis indicate that significant oil-type molecules remain in the aqueous phase when processed at 15-20 wt\% solids. Very preliminary testing with Tetraselmis suggests that approximately $10 \%$ of the organic material lost to the AHTL aqueous phase might be AHTL oil type compounds. The data also indicated that more oil is lost to the aqueous phase for Nannochloropsis processing than from Tetraselmis, which may indicate a lipid content effect coupled with solids loading. Product recovery by gravity separation alone is unlikely to recover all oil compounds with the AHTL oil phase. AHTL oil and aqueous phase separation needs further work to recover more of the organic material into the AHTL oil phase.

- Detailed characterizations of all the AHTL oil, aqueous phase, solids and gaseous products are needed. For example, better understanding of the quality and stability of the AHTL oil will help reveal the underlying HTL reactions and subsequent upgrading requirements. Currently, ultimate analysis, density, gas analysis and whole oil distillation curves are being collected. Analysis by GC/MS, HPLC, and ${ }^{13} \mathrm{C}$ NMR already being collected should continue. Understanding the speciation of alkanes/alkenes, aromatics, and oxygenates, particularly as a function of processing conditions, will help manage hydrogen usage. Off-gas composition by GC is available from the AHTL and hydrotreating experiments, but this may not be sufficient to assess the need for gas conditioning prior to final use, such as in a hydrogen plant.

- Characterization methods may need to be developed. Sudasinghe et al. (2013) noted that many analytical methods by themselves are not able to completely characterize AHTL product compounds. For example, chromatography methods lack resolution and selectivity, high molecular weight species go undetected, and highly polar compounds are not well addressed.

- Little is known about the stability of AHTL oil with time. This will be important when the upgrading facility is not co-located with the ATHL unit and the oil is transported offsite.

- Limited continuous flow conversion data are available. Processing a variety of algae grown under different conditions and varying solids loading, temperature, residence time and use of additives will help define the operating envelope.

- Corrosion data are needed to inform the choice of metallurgy. This could be similar to the corrosion work with ORNL on other types of liquefaction oils. 


\subsection{AHTL Oil Catalytic Upgrading Model Description and Input Data}

Hydrotreating removes oxygen, nitrogen, and sulfur and saturates olefins and aromatics. Upgrading AHTL oil to hydrocarbon oil is accomplished in a single catalytic step, both for the 2014 experimental work reported here and used in the SOT model and for the target (design) case projected to be achievable in 2022. All experimental hydrotreating work is performed in continuous flow fixed bed reactors using a cobalt based catalyst and operates at $1500 \mathrm{psig}$, approximately $750{ }^{\circ} \mathrm{F}\left(400{ }^{\circ} \mathrm{C}\right)$, with a liquid hourly space velocity, in the range of 0.2 to 0.27 volumes per hour of feed per reactor volume.

Table 3. Hydrotreating continuous flow experimental results used in the SOT model and projected 2022 model assumptions

\begin{tabular}{|c|c|c|}
\hline Operating Conditions and Results & $\begin{array}{l}\text { SOT Experimentally } \\
\text { Derived Model Inputs }\end{array}$ & $\begin{array}{c}2022 \text { Input to } \\
\text { Modeled Projection }\end{array}$ \\
\hline Temperature, ${ }^{\circ} \mathrm{F}\left({ }^{\circ} \mathrm{C}\right)$ & $752(400)$ & $757(403)$ \\
\hline Pressure, psia & $\sim 1515$ & 1515 \\
\hline $\begin{array}{l}\text { Experimental bed volume } \\
\text { Experimental catalyst loading } \\
\text { Experimental run length }\end{array}$ & $\begin{array}{c}20.3 \mathrm{~cm}^{3} \text { bed } \\
16 \text { g catalyst } \\
35.5 \text { hours }\end{array}$ & $\begin{array}{c}\text { Not } \\
\text { applicable }\end{array}$ \\
\hline $\begin{array}{l}\text { Catalyst } \\
\text { Sulfided? } \\
\text { LHSV, vol./hour / vol. catalyst } \\
\text { WHSV, wt/hour / wt catalyst }\end{array}$ & $\begin{array}{c}\text { CoMo/alumina-F } \\
\text { yes } \\
0.20,0.27 \\
0.24,0.34\end{array}$ & $\begin{array}{c}\text { CoMo/alumina } \\
\text { Purchased presulfided } \\
0.5 \\
0.625\end{array}$ \\
\hline $\begin{array}{l}\text { Chemical } \mathrm{H}_{2} \text { consumption, wt/wt raw } \\
\text { HTL bio-oil (wet) }\end{array}$ & $0.042,0.035$ & 0.043 \\
\hline $\begin{array}{l}\text { Products, wt \% } \\
\text { Hydrotreated oil } \\
\text { Aqueous phase } \\
\text { Gas } \\
\end{array}$ & $\begin{array}{c}85,86 \\
8,8 \\
7.2,6.9 \\
\end{array}$ & $\begin{array}{c}77 \\
16 \\
7\end{array}$ \\
\hline $\begin{array}{l}\text { Product oil, wt\% (dry basis) } \\
\text { C } \\
\text { H } \\
\text { O } \\
\text { N } \\
\text { S }\end{array}$ & $\begin{array}{c}84.9,83.9 \\
12.5,12.1 \\
1.05,0.9 \\
0.3,0.77 \\
<0.005,0.03\end{array}$ & $\begin{array}{c}86 \\
14 \\
<1 \\
<0.05 \\
0.0\end{array}$ \\
\hline Aqueous carbon, wt $\%$ & Not reported & 0.3 \\
\hline $\begin{array}{l}\text { Gas analysis, volume } \% \\
\mathrm{CO}_{2}, \mathrm{CO} \\
\mathrm{CH}_{4} \\
\mathrm{C}_{2}+ \\
\mathrm{NH}_{3}\end{array}$ & $\begin{array}{l}0,0 \\
47,47 \\
42,44 \\
12,9\end{array}$ & $\begin{array}{c}0 \\
45 \\
54 \\
1\end{array}$ \\
\hline TAN, feed (product) & $35.5(0.14,0.33)$ & Not calculated \\
\hline Viscosity@40 ㄷ, cSt, feed (product) & $149(1.50,1.64)$ & Aspen: (3.07) \\
\hline Density@40 ${ }^{\circ} \mathrm{C}, \mathrm{g} / \mathrm{cm}^{3}$, feed (product) & $0.964(0.785,0.791)$ & Aspen: $0.925(0.755)$ \\
\hline
\end{tabular}

Note that the carbon content of the 2014 SOT hydrotreated oil is $83-85 \mathrm{wt} \%$, thus fairly close to the $86 \%$ projected design case. The oxygen, nitrogen, sulfur and TAN values for the SOT cases are also close to 
approaching the design case assumptions. The projected catalyst life of 2 years is likely achievable given sufficient AHTL oil cleanup prior to hydrotreating to removed salts. This can be accomplished through counter current washing, similar to desalters used in a petroleum refinery to prepare crude oils for distillation.

Figure 3 shows the boiling point curve (SIMDIS) for the hydrocarbon oil resulting from hydrotreating AHTL oil. Note that experimentally varying the space velocity from 0.2 to 0.27 resulted in a small shift in the curve suggesting that the projected modeled LHVS of 0.5 may be achievable without greatly affecting oil quality. SIMDIS curves are used to determine the naphtha - diesel split in the models. The "Kerosene QC" and "Diesel QC" are quality control samples that also serve as a means of determining the proportions of the hydrotreated oil that fall into the jet (or kerosene) boiling range and the diesel boiling range.

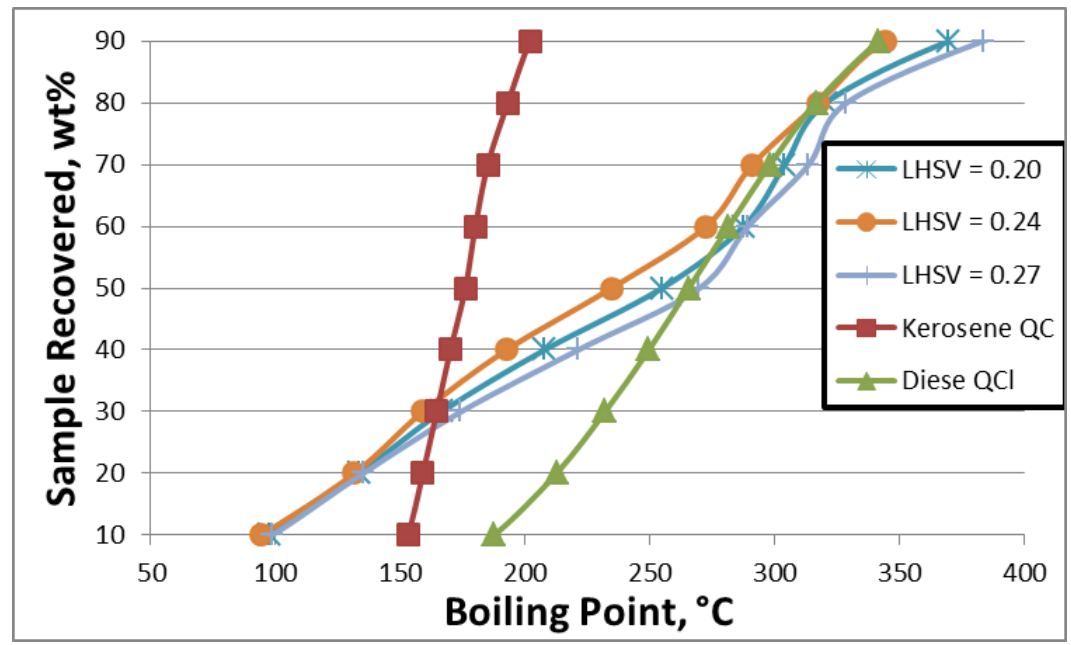

Figure 3. Experimentally derived hydrotreated AHTL oil distillation curves

Figure 4 shows the modeled product distribution, estimated from the SIMDIS curves. Future experimental work will distill the hydrotreated oil into their boiling fractions to better quantify the yields and the fuel quality, which in turn, will improve the modeled results. Section 1.5 discusses assumptions regarding further diesel production from the heavies.

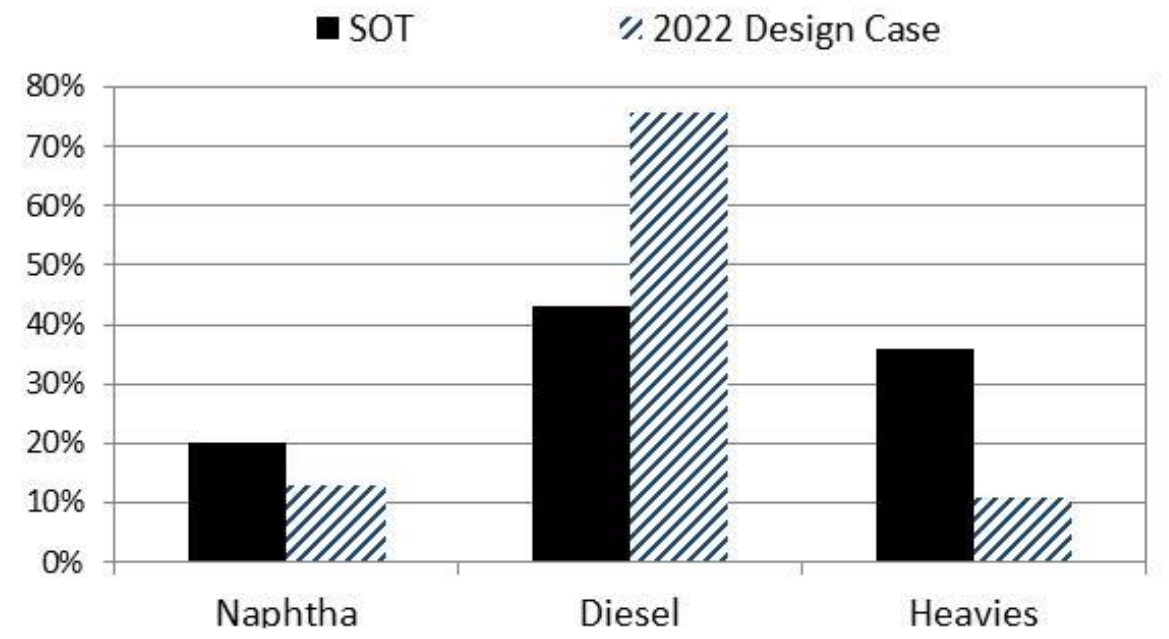

Figure 4. Estimated hydrotreated product distribution 
It is assumed for the 2014 SOT that the entire heavier-than-diesel boiling range product is finished in a hydrocracker to produce additional diesel range material. No data have been published in this area as of 2014 specifically for heavy AHTL oil, and research has not yet been conducted in this area in support of this SOT. The final, modeled yields after the inclusion of the hydrocracking assumptions and distillation are shown in Figure 5.

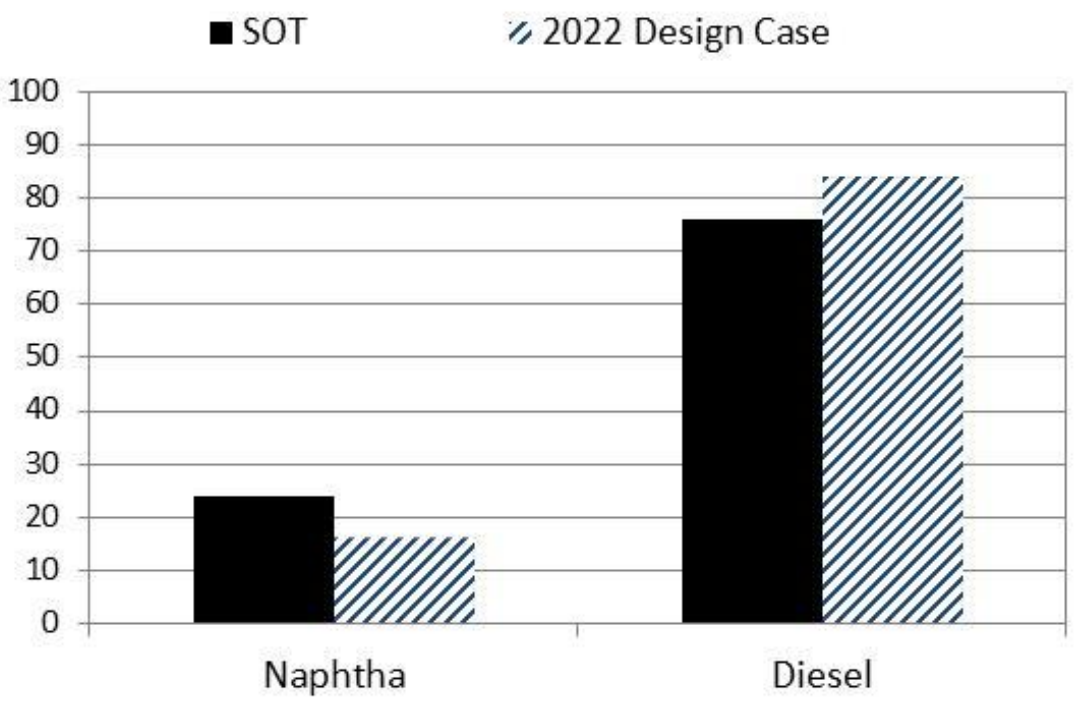

Figure 5. Modeled final product distribution

\section{Observations and Comments after Modeling AHTL Oil Upgrading}

- Improved catalyst performance needs examination. Hydrotreating catalyst maintenance and stability are unknown, as are regeneration protocols and lifetimes. Longer-term testing with AHTL oil and detailed characterization of catalyst performance and deactivation modes are needed. Pretreatment steps, such as desalting, need to be demonstrated.

- Development of deoxygenation and de-nitrogenation reaction kinetics would assist reactor designs and better inform the choice of co-processing in a petroleum refinery.

- Fuel quality characterization of the major distillation fractions, naphtha range, diesel range, and gas oil range for the AHTL oil and the hydrotreated oil needs examination. The jet fuel range should also be characterized, and an understanding of how to produce a jet cut without degrading naphtha and diesel properties would also be useful. Testing for key final fuel qualities, such as flash, octane, cetane, and cold flow properties is desirable.

- Hydrocracking yields of the gas oil fraction should be demonstrated. 


\subsection{Aqueous Phase Catalytic Hydrothermal Gasification (CHG) Model Description and Input Data}

Catalytic hydrothermal gasification used time, pressure, temperature and a catalyst to recover the organic material as a mixture of methane and carbon dioxide. The high water content coupled with the high pressure allows most of the produced carbon dioxide to remain in solution as a carbonate. Thus the recovered gas is rich in methane, making it useful as feed to the hydrogen plant and as fuel gas. The experimental data used for the modeled SOT case and the modeled projection for 2022 are shown in Table 4.

Table 4. CHG continuous flow experimental results and projected model assumptions

\begin{tabular}{|l|c|c|}
\hline \multicolumn{1}{|c|}{ Operating Conditions and Results } & $\begin{array}{c}\text { SOT Experimentally } \\
\text { Derived Model Inputs }\end{array}$ & $\begin{array}{c}\text { 2022 Input to Modeled } \\
\text { Projection }\end{array}$ \\
\hline Guard Bed & Raney nickel & Raney nickel \\
\hline Temperature, ${ }^{\circ} \mathrm{F}\left({ }^{\circ} \mathrm{C}\right)$ & $662(350)$ & $662(350)$ \\
\hline Pressure, psia & $3011 \pm 5$ & 2980 \\
\hline Catalyst & $7.8 \mathrm{wt} \% \mathrm{Ru} / \mathrm{C}$ & $7.8 \% \mathrm{Ru} / \mathrm{C}$ \\
LHSV, vol./hour per vol. catalyst & 2.0 & 2.0 \\
WHSV, wt./hr per wt. catalyst & 4.28 & 3.99 \\
\hline$\%$ COD conversion & $99.8 \%$ initial & $99.9 \%$ \\
$\%$ Carbon to gas ${ }^{1}$ & $12 \%$ & $57 \%$ \\
\hline Gas analysis, volume \% & 56 & 22 \\
$\mathrm{CO}_{2}$ & 3 & 0 \\
$\mathrm{H}_{2}$ & 39 & 71 \\
$\mathrm{CH}_{4}$ & 1 & 2 \\
$\mathrm{C}_{2}+$ & -- & -- \\
$\mathrm{N}_{2}$ & 3 & 5.8 \\
water $^{2}$ & 203 & Low, recycle treated water to \\
\hline Treated water COD & \\
\hline${ }^{1}$ Note that the remaining converted carbon is dissolved carbonate \\
\hline
\end{tabular}

Experimentally, although the COD conversion was initially high, processing issues caused a drop in carbon conversion as the run progressed. The catalyst was severely deactivated during the run, most likely by the significant sulfate levels in the feed (744 ppm). The sulfur scrubber bed traps only sulfides, whereas sulfates apparently pass through to the gasification catalyst. Thus, a true estimate of CHG catalyst life for use in the model is yet to be determined. However, a study by Elliott et al. (2006) using model compounds demonstrated good catalyst stability when sulfur is not present.

Experimentally, the AHTL aqueous phase contains considerable amounts of organic material, some of which could be recovered into the AHTL oil if better liquid/liquid phase separation could be achieved. The current experimental practice is to cool the liquid AHTL product and allow the two liquid phases to gravity separate. AHTL oil produced from marine type algae tends to better separate than that from freshwater types, suggesting dissolved salts improve oil hydrophobicity. Other options to enhance product recovery include oil/water separators and solvent extraction. 


\section{Observations after Modeling AHTL Water Treatment}

- The CHG tests reported here were limited and of short duration. Process optimization is needed as well as a better understanding of catalyst maintenance and costs.

- Effective means of sulfur removal prior to $\mathrm{CHG}$ are needed to reduce $\mathrm{CHG}$ catalyst deactivation rates.

- The extent of treatment needed to allow water recycle to the algae ponds without diminishing algae growth must be better understood.

\subsection{Balance of Plant Model Description}

The main contributor to the modeled balance of plant costs is from hydrogen generation via conventional natural gas steam reforming. It is assumed that off-gases from the AHTL reactor, the CHG reactor and from hydrotreating are combined and used in the hydrogen plant. As the combined off gases are not quite sufficient to meet the hydrogen demand for hydrotreating, natural gas is brought in to make up the difference. Verification that these combined gases can be successfully reformed without issue (such as impurity effects) has not been conducted in support of this SOT, and may require future work. 


\subsection{Environmental Sustainability Metrics}

In addition to setting economic trajectories toward BETO Programmatic Goals for the conversion pathways included in the MYPP, BETO is evaluating the modeled environmental performance of conversion pathways. The following environmental considerations are currently being assessed: greenhouse gas (GHG) emissions, fossil energy consumption, fuel yield, carbon-to-fuel efficiency, water consumption, and wastewater generation. Shown in Table 5 are the estimated metric values for the 2014 SOT cases and the 2022 projected case. The cases shown align with the corresponding cost year scenarios presented in Table 6 , the models for which are based on the 2014 AHTL design case.

Table 5. Sustainability metrics

\begin{tabular}{|c|c|c|c|}
\hline Sustainability Metric & Units & 2014 SOT & $\begin{array}{l}2022 \text { Modeled } \\
\text { Projection }\end{array}$ \\
\hline $\begin{array}{l}\text { Conversion Plant GHG } \\
\text { emissions - fossil; } \\
\text { biogenic }^{1}\end{array}$ & $\mathrm{~g} \mathrm{CO}_{2}$-e/MJ fuel & $\begin{array}{l}12.4 \text { (20.0 including } \\
\text { summer algae drying); } \\
\quad 42.5\end{array}$ & $\begin{array}{l}9.1 \text { (14.0 including } \\
\text { summer algae); } \\
\quad 20.4\end{array}$ \\
\hline $\begin{array}{l}\text { Conversion Plant Fossil } \\
\text { Energy Consumption }\end{array}$ & MJ fossil energy/MJ fuel ${ }^{2}$ & $\begin{array}{l}0.18 \text { (0.31 including } \\
\text { summer algae drying) }\end{array}$ & $\begin{array}{c}0.14 \text { (0.22 including } \\
\text { summer algae drying) }\end{array}$ \\
\hline Diesel Fuel Yield & $\begin{array}{l}\text { gallon diesel/ dry ton ash } \\
\text { free algae }\end{array}$ & 77 & 122 \\
\hline Naphtha Fuel Yield & $\begin{array}{l}\text { gallon naphtha/dry ton ash } \\
\text { free algae }\end{array}$ & 25 & 25 \\
\hline $\begin{array}{l}\text { Biomass Carbon-to- } \\
\text { Diesel + Naphtha } \\
\text { Efficiency }\end{array}$ & $\begin{array}{l}\% \text { of algal carbon in liquid } \\
\text { fuel product }\end{array}$ & 59 & 70 \\
\hline $\begin{array}{l}\text { Conversion Plant Water } \\
\text { Consumption }\end{array}$ & $\mathrm{m}^{3} /$ day; gal/gal diesel ${ }^{3}$ & $393 ; 1.01$ & $1126 ; 1.81$ \\
\hline $\begin{array}{l}\text { Conversion Plant } \\
\text { Wastewater Generation }\end{array}$ & $\mathrm{m}^{3} /$ day; gal/gal diesel ${ }^{3}$ & \multicolumn{2}{|c|}{ None, conversion plant water is recycled to ponds } \\
\hline \multicolumn{4}{|c|}{$\begin{array}{l}{ }^{1} \text { Biogenic emission values do not include dissolved } \mathrm{CO}_{2} \text { and } \mathrm{CH}_{4} \text { in wastewater recycled to the farm. } \\
{ }^{2} \text { Fossil energy consumption does not include power used by algae farm for cultivation, harvest and dewatering. } \\
{ }^{3} \text { Water consumption and wastewater generation include only direct use/emissions and do not include water associated } \\
\text { with upstream production of materials and energy used at the plant. }\end{array}$} \\
\hline
\end{tabular}

It is known that different types of algae will process in different ways. Choosing and/or developing an optimal strain or strains will strongly contribute to meeting the 2022 projections. This differs from previous terrestrial biomass cases where a single feedstock type was used as a standard for SOT analysis (i.e., low ash wood for thermochemical conversion, and corn stover for biochemical conversion). 


\section{Observations and Comments after Modeling with regard to Sustainability, Economic and}

Environmental

- Nutrient recycle has been identified by the harmonization work as a key driver in meeting GHG reduction goals in the life cycle assessment. A preliminary assessment of nutrient partitioning is in Jones et al. (2014); however, cultivation with real recycle should be demonstrated.

- HTL and CHG are each high pressure, heated processes. Opportunities for integrating them to avoid cooling and reheating and de-pressuring and re-pressuring may reduce energy demands.

- Most of the phosphorus (90\%) is bound in the AHTL solids and will likely require some type of conversion (such as acid digestion) to make it bio-available. This will require experimental verification.

- The life cycle analysis conducted for the harmonization work should be extended to the target case. The addition of other sustainability metrics such as energy return on investment may also be useful.

- Co-product opportunities have the potential to further lower the cost of hydrocarbon production from algal biomass and will be considered where possible. However, it is necessary to ensure that the volumes of co-products produced will not overwhelm market demand. 


\subsection{Conversion Progression to 2022 Design Case}

As discussed in the introduction, the experimental data are used to measure progress towards technical targets. The experimental data are also used in commercial scale models to estimate the cost of production and compare with cost targets. Figure 6 shows the modeled SOT conversion cost contributions by area in comparison to the 2022 projected costs. Table 6 shows the detailed cost breakouts for the SOT and the 2022 projection. All financial and economic assumptions are in accordance with standard BETO methods and consistent with those used in Jones et al. (2014).

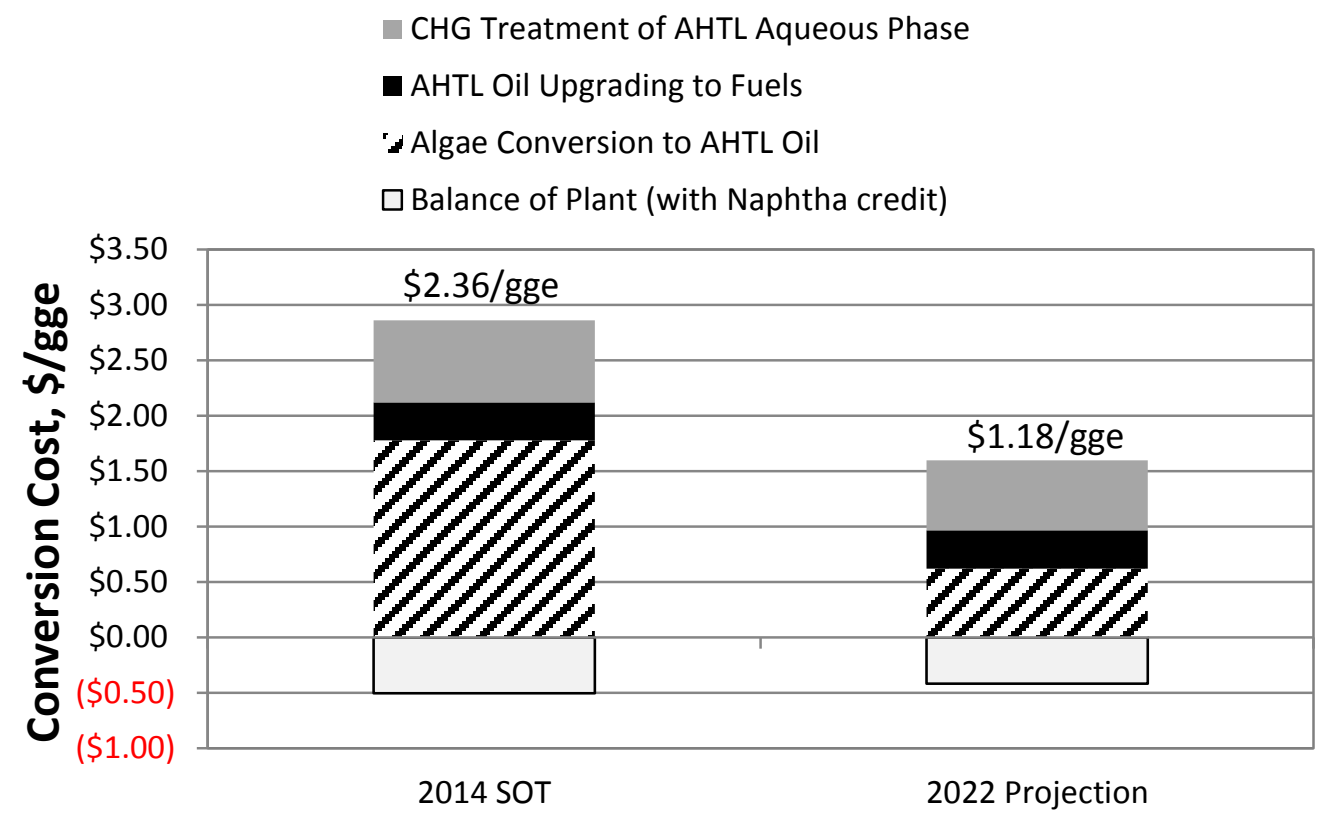

Figure 6. Modeled conversion cost progression

The basis for the SOT case assumed here is an algae farm operating at $30 \mathrm{~g} / \mathrm{m}^{2} /$ day and producing a yearly average of 1340 tons per day of algae (dry and ash free basis) delivered to the AHTL plant as $20 \mathrm{wt} \%$ solids slurry. This in turn is based on the 10,000 acres of ponds assumed in the harmonization work. All algal conversion steps to finished diesel are assumed to take place adjacent to the algae farm. This is unlikely to be the case and future work should be directed towards assessing small on farm AHTL with water treatment, and offsite large scale centralized hydrotreating to produce a finished fuel.

From Table 6, it is apparent that the cost to produce dewatered algae is a significant factor affecting the final fuel cost. The algae feedstock cost (accounting for cultivation, harvest and dewatering) are taken from the Multi-year Program Plan (U.S. DOE 2014). This is a placeholder value that will be updated in the future when a farm model that is optimized towards AHTL processing becomes available. Additionally, algal strain development is needed to optimize desirable characteristics such as rapid growth rate.

The key conversion improvements needed are in the area of improved AHTL oil separation from the AHTL aqueous phase. Efficient ATHL oil cleanup (e.g. washing steps) prior to hydrotreating will improve hydrotreating catalyst maintenance. AHTL aqueous phase catalyst maintenance needs are still to be determined. Capital cost reduction is possible in all three major steps through optimization of reaction time 
and temperature. This can be seen in Figure 7 by comparing the AHTL cost contribution. The 2022 projection assumes that the AHTL residence time can be halved, thus reducing the reactor capital cost.

The key analytical needs are complete characterization of all the AHTL phases, particularly in terms of types of compounds produced by different types of algae. This will assist in devising effective means for oil/water separation. It is also necessary to fractionate the hydrotreated product into naphtha and diesel fractions and characterize those fractions with respect to standard fuel measures such as flashpoint and octane for the naphtha cut and cetane and freeze point for the diesel cut.

Table 6. Modeled costs for the 2014 SOT and the 2022 projection

\begin{tabular}{|c|c|c|c|}
\hline $\begin{array}{l}\text { Processing Area Cost Contributions \& } \\
\text { Key Technical Parameters }\end{array}$ & Units & 2014 SOT & 2022 Projected \\
\hline Diesel selling price & $\$ /$ gal diesel & $\$ 15.57$ & $\$ 4.49$ \\
\hline Conversion Contribution, Diesel & $\$ / G G E$ & $\$ 2.36$ & $\$ 1.18$ \\
\hline Performance Goal & \$/GGE & & $\$ 3$ \\
\hline Diesel Production & $\mathrm{mm}$ gallons/yr & 34 & 54 \\
\hline Production Co-Product Naphtha & $\mathrm{mm}$ gallons/yr & 11 & 11 \\
\hline Diesel Yield (AFDW algae basis) & $\begin{array}{l}\text { gal/US ton } \\
\text { algae }\end{array}$ & 77 & 122 \\
\hline Naphtha Yield (AFDW algae basis) & gal/us ton algae & 25 & 25 \\
\hline Natural Gas Usage (AFDW algae basis) & $\begin{array}{l}\text { scf/US ton } \\
\text { algae }\end{array}$ & 2,805 & 2,946 \\
\hline \multicolumn{4}{|l|}{ Feedstock } \\
\hline Total Cost Contribution & \$/gge fuel & $\$ 13.21$ & $\$ 3.31$ \\
\hline Feedstock Cost (AFDW algae basis) & $\$ /$ US ton algae & $\$ 1,092$ & $\$ 430$ \\
\hline \multicolumn{4}{|l|}{$\overline{A H T L}$} \\
\hline Total Cost Contribution & \$/gge fuel & $\$ 1.78$ & $\$ 0.62$ \\
\hline Capital Cost Contribution & \$/gge fuel & $\$ 1.36$ & $\$ 0.46$ \\
\hline Operating Cost Contribution & \$/gge fuel & $\$ 0.42$ & $\$ 0.16$ \\
\hline AHTL Oil Yield (dry) & $\mathrm{lb} / \mathrm{lb}$ algae & 0.40 & 0.59 \\
\hline \multicolumn{4}{|l|}{ AHTL Oil Hydrotreating to Finished Fuels } \\
\hline Total Cost Contribution & \$/gge fuel & $\$ 0.34$ & $\$ 0.35$ \\
\hline Capital Cost Contribution & \$/gge fuel & $\$ 0.22$ & $\$ 0.14$ \\
\hline Operating Cost Contribution & \$/gge fuel & $\$ 0.12$ & $\$ 0.21$ \\
\hline Mass Yield on dry AHTL Oil & lb/lb AHTL oil & 0.86 & 0.83 \\
\hline \multicolumn{4}{|c|}{ Catalytic Hydrothermal Gasification of AHTL Aqueous Phase } \\
\hline Total Cost Contribution & \$/gge fuel & $\$ 0.74$ & $\$ 0.63$ \\
\hline Capital Cost Contribution & \$/gge fuel & $\$ 0.39$ & $\$ 0.37$ \\
\hline Operating Cost Contribution & \$/gge fuel & $\$ 0.35$ & $\$ 0.26$ \\
\hline \multicolumn{4}{|l|}{ Balance of Plant } \\
\hline Total Cost Contribution & \$/gge fuel & $(\$ 0.50)$ & $(\$ 0.42)$ \\
\hline Capital Cost Contribution & \$/gge fuel & $\$ 0.24$ & $\$ 0.18$ \\
\hline Operating Cost Contribution & \$/gge fuel & $\$ 0.24$ & $\$ 0.04$ \\
\hline Naphtha Credit (\$3.25/gal) & \$/gge fuel & $(\$ 0.99)$ & $(\$ 0.63)$ \\
\hline Models: Case References & & T091014-SOT & $030114 \mathrm{P}$ \\
\hline
\end{tabular}




\subsection{References}

Davis, R., D. Fishman, E. Frank, M. Johnson, S. Jones, C. Kinchin, R. Skaggs, E. Venteris, M. Wigmosta. 2014. "Integrated Evaluation of Cost, Emissions, and Resource Potential for Algal Biofuels at the National Level.” Environmental Science \& Technology 48:6035-6042.

EcoInvent Database 2011, Version 2.2, Hamburg, Germany: Swiss Center for Life Cycle Inventories.

Elliott, DC, TR Hart, GG Neuenschwander. 2006. "Chemical Processing in High-Pressure Aqueous Environments. 8. Improved Catalysts for Hydrothermal Gasification” Ind. Eng. Chem. Res. 45:3776-3781

Jones SB, Y Zhu, DM Anderson, R Hallen, DC Elliott, A Schmidt, K Albrecht, T Hart, M Butcher, C Drennan, LJ Snowden-Swan, R Davis, C Kinchin. 2014, "Process Design and Economics for the Conversion of Algal Biomass to Hydrocarbons: Whole Algae Hydrothermal Liquefaction and Upgrading." PNNL-23227 Pacific Northwest National Laboratory, Richland WA http://www.pnnl.gov/main/publications/external/technical reports/PNNL-23227.pdf

SimaPro 2011. Life Cycle Assessment Software v. 7.3, Amersfoort, the Netherlands: Product Ecology Consultants.

Sudasinghe, Nilusha, B. Dungan, P. Lammers, K. Albrecht, D. Elliott, R. Hallen, T. Schaub. 2014. "High resolution FT-ICR mass spectral analysis of bio-oil and residual water soluble organics produced by hydrothermal liquefaction of the marine microalga Nannochloropsis salina." Fuel 119:47-56.

U.S. Department of Energy. 2014. Bioenergy Technologies Office Multi-Year Program Plan. July 2014. Bioenergy Technologies Office, Energy Efficiency and Renewable Energy, U.S. Department of Energy, Washington DC http://www.energy.gov/sites/prod/files/2014/07/f17/mypp july 2014.pdf

U.S. Life Cycle Inventory Database 2012. National Renewable Energy Technology Laboratory, 2012. https://www.lcacommons.gov/nrel/search. 


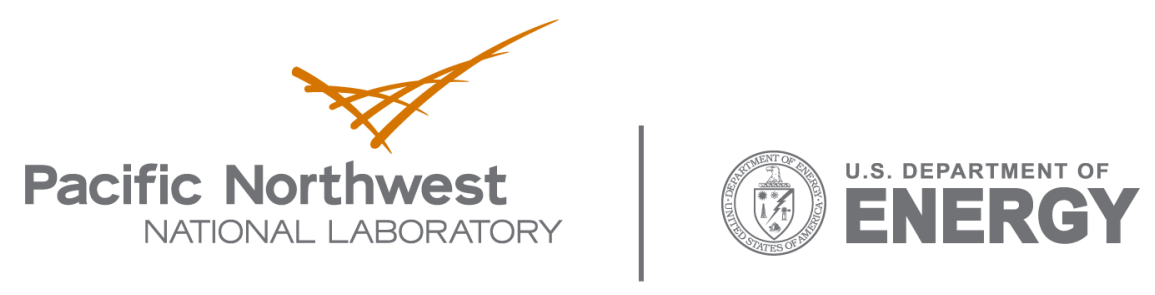

902 Battelle Boulevard

P.O. Box 999

Richland, WA 99352

1-888-375-PNNL (7665)

www.pnl.gov 